\title{
RESEARCH NOTE \\ Nutraceutical quality of cantaloupe melon fruits produced under fertilization with organic nutrient solutions
}

\author{
Pablo Preciado-Rangel ${ }^{1}$, Karla M. García-Villela ${ }^{1}$, Manuel Fortis- \\ Hernández ${ }^{1}$, Radamés Trejo Valencia ${ }^{2}$, Edgar O. Rueda Puente ${ }^{3}$, and Juan R. \\ Esparza-Rivera ${ }^{4}$
}

${ }^{1}$ Instituto Tecnológico de Torreón. Carretera Torreón-San Pedro Km 7.5. Ejido Ana. Torreón, Coahuila, Mexico. ${ }^{2}$ Instituto Tecnológico de Minatitlán, Blvd. Institutos Tecnológicos S/N, Col. Buena Vista Norte, Minatitlán, Ver. Mexico.

${ }^{3}$ Universidad de Sonora, Boulevard Luis Encinas y Rosales, Col. Centro, 23000 Hermosillo, Sonora, Mexico.

${ }^{4}$ Facultad de Ciencias Químicas Gómez Palacio, Universidad Juárez del Estado de Durango. Avenida Artículo 123 S/N, Fraccionamiento Filadelfia. Gómez Palacio, Durango, Mexico.

\begin{abstract}
P. Preciado-Rangel, K.M. García-Villela, M. Fortis-Hernández, R. Trejo Valencia, E.O. Rueda Puente, and J.R. Esparza-Rivera. 2015. Nutraceutical quality of cantaloupe melon fruits produced under fertilization with organic nutrient solutions. Cien. Inv. Agr. 42(3): 475-481. Consumption of fruits and vegetables provides natural antioxidants in the human diet that are capable of preventing diseases resulting from the action of free radicals. The aim of the current study was to evaluate the effect of organic nutrient solutions on the nutraceutical quality of hydroponic cantaloupe melon (Cucumis melo L.) produced under greenhouse conditions. The applied organic solutions consisted of compost and vermicompost teas and vermicompost leachate, while Steiner nutrient solution was used as a control. Analytical tests were run to determine the antioxidant capacity and total phenolic content of the melon fruits. The nutraceutical quality (antioxidant capacity and phenolic content) of the fruits fertilized with the organic solutions was higher than that of melons fertilized using Steiner solution. Treatment with vermicompost leachate led to the highest antioxidant capacity and phenolic content among all of the treatments, resulting a $46.1 \%$ higher in antioxidant capacity $\left(\mathrm{DPPH}^{+}\right.$method) and a $29.3 \%$ higher phenolic content compared with inorganically fertilized fruits. Vermicompost solutions (leachate and tea) are viable alternatives for use as a nutrient source in the production of hydroponic cantaloupe melon with improved nutraceutical quality under greenhouse conditions.
\end{abstract}

Key words: Antioxidant capacity, Cucumis melo, nutraceutical, organic fertilization.

\section{Introduction}

Consumption of fruits and vegetables in the diet has been promoted in recent years for sev-

Received February 1, 2015. Accepted September 28, 2015 Corresponding author: jresparza02001@yahoo.com eral reasons, including benefits associated with the prevention of cancer and degenerative and cardiovascular diseases (Guerrero et al., 2010). Moreover, consumption of organic food products has increased recently because consumers are demanding high-quality fresh products that are safe and pesticide-free (Hallmann and 
Rembiałkowska, 2012) and are produced using environmentally friendly production systems (Bourn and Prescott, 2002; Zhao et al., 2006). An additional advantage of organic horticultural produce is its better nutraceutical quality due to higher contents of ascorbic acid, phenolics, total sugars and antioxidant compounds (Guerrero et al., 2010; Hallmann and Rembiałkowska, 2012). A nutraceutical is any substance that is a food or a part of food that provides medical or health benefits, including prevention and treatment of disease (DeFelice, 1995). The importance of antioxidants to human health has led to the development of studies in the areas of agronomic and food science to evaluate the effect of a number of agricultural practices, such as fertilization, on the type and contents of antioxidants in fruits and vegetables. An alternative that has been used to manipulate the synthesis of antioxidants and phytochemical compounds in vegetable produce is the application of organic fertilizers (Benavides-Mendoza, 2002), including organic nutrient solutions, such as compost and vermicompost teas (PreciadoRangel et al., 2011). Moreover, it is known that the most efficient practice for supplying fertilizer is through the irrigation water (fertigation) as a nutritional solution (Ferrante et al., 2008). However, these nutritive solutions must be diluted to avoid phytotoxicity, thereby reducing the nutrient supply, which may represent an additional stress for growing plants.

The aim of the current study was to evaluate the nutraceutical quality of cantaloupe melon fruits fertilized with different organic fertilizer solutions.

\section{Materials and methods}

Vegetal and growth conditions of plant material

The study was performed in an automatic tunneltype greenhouse covered with plastic, with an area of $144 \mathrm{~m}^{2}$, located at the ITT (Instituto Tecnológico de Torreón) in Torreón, Coahuila
(Mexico) between $24^{\circ} 30^{\prime}$ and $27^{\circ} \mathrm{N}$ and $102^{\circ} 00^{\prime}$ and $104^{\circ} 40^{\prime} \mathrm{W}$, at an altitude of 1,120 masl.

Cantaloupe melon (Cruisier hybrid) was produced under greenhouse conditions during the autumnwinter season of 2012. Sowing was performed by placing seeds in a 200-well polystyrene container containing wet PeatMoss (Premier Promix PGX, Quebec, Canada) as a substrate (one seed per well). The container was then covered with black plastic and irrigated by spraying three times a day until seed germination. When the seedlings reached a height of 15-20 cm and exhibited 3-4 real leaves, they were transplanted into $20 \mathrm{~L}$ black plastic bags as pots, which contained river sand and perlite (80:20) as a hydroponic substrate (one seedling per pot). The river sand was previously washed and sanitized using a $5 \%$ sodium hypochloride solution. The pots were then sorted into a double line, with a distance $1.6 \mathrm{~m}$ between the lines and $1.5 \mathrm{~m}$ between the plants within the row, at a plant density of 4.2 plants $\mathrm{m}^{-2}$. A drip irrigation system was used to irrigate the plants by spraying three times per day, with a volume of $0.500 \mathrm{~L} \mathrm{pot}^{-1}$ day $^{-1}$ from transplantation to flowering and $1.0 \mathrm{~L} \mathrm{pot}^{-1} \mathrm{day}^{-1}$ from flowering to harvest. Polinization was performed manually every day at 12:00-14:00, from the beginning of flowering to fruit development. The plants were pruned to a single stem, which was attached with string to the greenhouse frame, while the fruits were placed in plastic mesh pockets tied to the support structure.

\section{Treatments}

The applied fertilization treatments consisted of an inorganic nutrient solution (Steiner, 1984); compost tea; and vermicompost tea and leachate (leachate collected from vermicompost production), according to Preciado-Rangel et al. (2011). The inorganic nutrient solution (Steiner, 1984) was prepared using highly soluble commercial fertilizers. The fertilizer solutions were adjusted to a $\mathrm{pH}$ of 5.5 and an electrical conductivity (EC) 
of $2.0 \mathrm{dS} \mathrm{m}^{-1}$ via dilution with tap water to avoid phytotoxicity (Table 1). The treatments were established in a completely randomized design using 10 plants per treatment, with each plant representing a treatment replicate.

Table 1. Chemical composition of the nutrient solutions applied during the production of hydroponic cantaloupe melon in a greenhouse.

\begin{tabular}{|c|c|c|c|c|}
\hline & $\begin{array}{l}\text { Steiner } \\
\text { Solution }\end{array}$ & $\begin{array}{c}\text { Compost } \\
\text { tea }\end{array}$ & $\begin{array}{l}\text { Vermicompost } \\
\text { tea }\end{array}$ & $\begin{array}{c}\text { Vermicompost } \\
\text { leachate }\end{array}$ \\
\hline & & & $\left(\mathrm{mg} \mathrm{L}^{-1}\right)$ & \\
\hline $\mathrm{N}$ & 168 & 21 & 24 & 19 \\
\hline$P$ & 31 & 13 & 15 & 11 \\
\hline K & 273 & 255 & 350 & 245 \\
\hline $\mathrm{Ca}$ & 180 & 15 & 17 & 19 \\
\hline $\mathrm{Mg}$ & 48 & 17 & 19 & 11 \\
\hline $\mathrm{Na}$ & $36^{1}$ & 4081 & 3736 & 2388 \\
\hline S & 336 & 599 & 831 & 437 \\
\hline $\mathrm{Cl}$ & $199^{1}$ & 713 & 589 & 634 \\
\hline
\end{tabular}

${ }^{1}$ water used for solution preparation.

\section{Analytical tests}

The evaluated variables were the phenolic content and antioxidant capacity $\left(\mathrm{ABTS}^{+}\right.$and $\mathrm{DPPH}^{+}$ methods), as indicators of the nutraceutical quality of the melon fruit.

Extract preparation. A sample of $5 \mathrm{~g}$ (fresh cantaloupe melon pulp) was mixed with $10 \mathrm{~mL}$ of methanol in a screw cap plastic tube, which was then placed in a shaker (ATR Inc., USA) for $6 \mathrm{~h}$ $(20 \mathrm{rpm})$ at $5^{\circ} \mathrm{C}$. The tubes were then centrifuged at $3000 \mathrm{rpm}$ for $10 \mathrm{~min}$, and the supernatant was extracted for analytical tests.

Total phenolic content. The total phenolic content was determined using a modified version of the Folin-Ciocalteau method (Esparza-Rivera et al., 2006). A $30 \mu \mathrm{L}$ aliquot of the simple extract was mixed with $270 \mu \mathrm{L}$ of distilled water and 1.5 $\mathrm{mL}$ of diluted (1:15) Folin-Ciocalteau reagent (Sigma-Aldrich, St. Louis MO, USA), followed by vortexing for 10 seconds. After $5 \mathrm{~min}, 1.2 \mathrm{~mL}$ of sodium carbonate $(7,5 \% \mathrm{w} / \mathrm{v})$ was added, and the mixture was vortexed again for 10 seconds. Next, the mixture was placed in a hot water bath at $45^{\circ} \mathrm{C}$ for $15 \mathrm{~min}$ and then allowed to cool at room temperature. The absorbance of the solution was read at $765 \mathrm{~nm}$ in a HACH 4000 spectrophotometer (Hach Company, Loveland, CO, USA). The phenolic content was calculated using a standard curve with gallic acid (Sigma, St. Louis, Missouri, USA) as a reference standard, and the results were reported in $\mathrm{mg}$ of gallic acid equivalents per $\mathrm{g}$ of fresh weight (mg equiv $\mathrm{AG} \mathrm{g}^{-1} \mathrm{FW}$ ). The analyses were run in triplicate.

Antioxidant capacity equivalent to Trolox $\left(\mathrm{DPPH}^{+}\right.$ method). The antioxidant capacity equivalent to Trolox was evaluated using a modified version of the method reported by Brand-Williams et al. (1995). A DPPH ${ }^{+}$methanolic solution was prepared, and the absorbance of the solution was adjusted to $1.100 \pm 0.010$ at a wavelength of $515 \mathrm{~nm}$. The antioxidant capacity test was run by mixing 50 $\mu \mathrm{L}$ of sample extract and $0.950 \mathrm{~mL}$ of $\mathrm{DPPH}^{+}$ solution, and the absorbance of the mixture was then read after $3 \mathrm{~min}$ of reaction at a wavelength of $515 \mathrm{~nm}$. A standard curve was prepared with Trolox (Aldrich, St. Louis, Missouri, USA), and the results are reported as $\mu \mathrm{M}$ equivalent to Trolox per $g$ of fresh weight ( $\mu \mathrm{M}$ equiv Trolox $\mathrm{g}^{-1} \mathrm{~m} \mathrm{FW}$ ). The analyses were run in triplicate.

\section{Antioxidant capacity equivalent to Trolox $\left(A B T S^{+}\right.$} method). The antioxidant capacity equivalent to Trolox was evaluated according to the in vitro $\mathrm{ABTS}^{+}$method reported by Esparza-Rivera et al. (2006). An $\mathrm{ABTS}^{+}$solution was prepared by mixing $40 \mathrm{mg}$ of ABTS (Aldrich, St. Louis, Missouri, USA) and $1.5 \mathrm{~g}$ of manganese dioxide (Fermont, Nuevo León, Mexico) in $15 \mathrm{~mL}$ of distilled water. The sample was agitated and allowed to rest for 20 minutes, then filtered through Whatman 40 paper (GE Healthcare UK Limited, Little Chalfont, Buckinghamshire, England). The absorbance of the filtered solution was adjusted using $5 \mathrm{mM}$ phosphate buffer to an absorbance of $0.700 \pm 0.010$ at a wavelength of $734 \mathrm{~nm}$. The antioxidant capacity test was run by mixing 100 
$\mu \mathrm{L}$ of the sample extract and $1 \mathrm{~mL}$ of $\mathrm{ABTS}^{+}$ solution, and the absorbance of the mixture was then read after 60 and 90 seconds of reaction at a wavelength of $734 \mathrm{~nm}$. A standard curve was prepared with Trolox (Aldrich, St. Louis, Missouri, USA), and the results are reported as $\mu \mathrm{M}$ equivalent to Trolox per $\mathrm{g}$ of fresh weight $(\mu \mathrm{M}$ equiv Trolox $\mathrm{gm}^{-1} \mathrm{FW}$ ). The analyses were run in triplicate.

\section{Statistical analysis}

The data for all of the evaluated variables were analyzed via ANOVA, and comparisons of means were conducted using the Tukey test $(\mathrm{P} \leq 0.05)$.

\section{Results and discussion}

The nutritional content of vegetable produce is affected by multiple factors, such as genetics (plant crop and cultivar) (Zhao et al., 2006) and environmental factors (soil type, climate conditions, irrigation and cultivation practices) (Bourn and Prescott, 2002), including fertilization (organic and conventional) (Lombardi-Boccia et al., 2004). The results obtained in this experiment showed that the nutrient solutions affected the antioxidant capacity and phenolic content of hydroponic cantaloupe melon. Moreover, the vermicompost leachate treatment led to the highest antioxidant capacity and phenolic content in the melons (Table 2), resulting in a $46.1 \%$ higher antioxidant capacity (DPPH method ${ }^{+}$) and $29.3 \%$ higher phenolic content compared with inorganically fertilized fruits. The differences between the treatments regarding the antioxidant capacity and phenolic contents of the melon fruits could be attributed to the low nutritional content of the applied diluted organic solutions (Table 1) (Zhao et al., 2006). Low contents of nitrogen, magnesium and phosphorous in the organic fertilizer solutions could cause nutritional stress in melon plants during growth, promoting increases in phenolic compound production, resulting in a higher antioxidant capacity of organic fruits. The applied organic solutions also contained low levels of calcium. However, calcium is known to affect parameters related to the commercial quality of fruit (Ochmian, 2012) and normal plant growth (Tuteja and Mahajan, 2007), in addition to its adverse effect on the content of polyphenols and vitamin $\mathrm{C}$ in fruits (Ochmian, 2012). Thus, it is assumed that the low level of calcium in the organic solutions did not affect the antioxidant capacity of the organic melons that were produced. There is evidence that the application of different levels of the macronutrient nitrogen via fertigation does not affect the phenolic content of melon fruits obtained under open field conditions (Ferrante et al., 2008). Other researchers have reported that the production of nitrogen-containing compounds, such as amino acids, proteins and alkaloids, increases in crops under production systems with a sufficient nitrogen supply (Hallmann and Rembiałkowska, 2012). Nevertheless, Herms and Mattson (1992) found that plants produce greater amounts of sugars (simple and complex) and secondary metabolites (pigments, vitamins, organic acids, terpenoides and phenolic compounds) when subjected to a deficit of the soluble nitrogen supply, which occurred in the present study in the melon plants fertilized with the organic nutrient solutions. Regarding phosphorous and magnesium, the low levels of these nutrients in the organic solutions could have contributed to increases in the phenolic content and antioxidant capacity of the fruits, as a response to such nutritional deficits during plant growth. This possibility is in agreement with the findings of Olivos et al. (2012), who reported that nectarine plants subjected to a low phosphorous supply exhibited higher phenolic content and antioxidant capacity in their fruits, while Dixon and Paiva (1995) reported that magnesium deficiency during plant growth increases phenolic concentrations in fruits and other tissues. The antioxidant capacity of the organic melons produced in the present study was higher than those fertilized using an inorganic nutrient solution. These results agree with other 
researchers who have reported a higher antioxidant capacity and phenolic content in melons (Salandanan et al., 2009), tomatoes (Toor et al., 2006), strawberries (Häkkinen and Törroönen, 2000), and apples (Weibel et al., 2000) grown under organic an nutrient supply compared with chemically fertilized fruits. Hence, it is feasible to recommend the application of organic nutrient solutions, such as vermicompost leachate and tea, as fertilizer alternatives for the production of hydroponic cantaloupe melon with an improved nutraceutical quality.
The main conclusions of the present study are as follows. The applied nutrient solutions (compost tea, vermicompost tea and leachate, and inorganic Steiner solution) affected the nutraceutical quality of melon, as the fruits produced using the organic solutions exhibited higher antioxidant capacity and phenolic content than the chemically fertilized melons. It is feasible to recommend the application of vermicompost nutrient solutions (leachate and tea) as fertilizer alternatives for the production of hydroponic cantaloupe melon with an improved nutraceutical quality.

Table 2. Antioxidant capacity and total phenolic content of hydroponic cantaloupe melon fruits produced using different nutrient solutions.

\begin{tabular}{lccc}
\hline & $\begin{array}{c}\text { Total phenolic content } \\
(\mathrm{mg} \text { equiv. Gallic acid } 100 \\
\left.\mathrm{g}^{-1} \mathrm{FW}^{1}\right)\end{array}$ & $\begin{array}{c}\text { Antioxidant capacity } \mathrm{ABTS}^{+} \\
\text {method } \\
\text { Treatments }\end{array}$ & $\begin{array}{c}\text { Antioxidant capacity DPPH } \\
\text { method }\end{array}$ \\
Steiner solution & $5.29 \mathrm{ab}$ & $365.2 \mathrm{~b}$ & $\begin{array}{c}\mathrm{FW}^{+} \\
\left(\mu \mathrm{M} \text { equiv. Trolox 100 } \mathrm{g}^{-1}\right.\end{array}$ \\
Compost tea & $4.56 \mathrm{~b}$ & $307.4 \mathrm{~b}$ & $873.2 \mathrm{c}$ \\
Vermicompost tea & $4.90 \mathrm{~b}^{2}$ & $449.1 \mathrm{ab}$ & $2193.3 \mathrm{a}$ \\
Vermicompost leachate & $6.84 \mathrm{a}$ & $533.7 \mathrm{a}$ & $1719.7 \mathrm{~b}$ \\
\hline
\end{tabular}

${ }^{1} \mathrm{FW}$ fresh weight.

${ }^{2}$ Values followed by different letters in the columns are significantly different (Tukey, $\mathrm{P} \leq 0.05$ ).

\section{Resumen}

P. Preciado-Rangel, K.M. García-Villela, M. Fortis-Hernández, R. Trejo Valencia, E.O. Rueda Puente y J.R. Esparza-Rivera. 2015. Calidad nutracéutica de melon cantaloupe producido bajo fertilización con soluciones nutritivas orgánicas. Cien. Inv. Agr. 42(3): 475-481. El consumo de frutas y vegetales incluye antioxidantes naturales a la dieta humana, los cuales son capaces de prevenir enfermedades derivadas de la acción de radicales libres. El objetivo del presente estudio fue evaluar el efecto de soluciones nutritivas orgánicas sobre la calidad nutraceutica de melón Cantaloupe (Cucumis melo L.) producido bajo condiciones de invernadero. Las soluciones orgánicas usadas fueron tés de compost y de vermicompost, lixiviado de vermicompost, y solución nutritiva Steiner como control. Las pruebas analíticas realizadas fueron: capacidad antioxidante y contenido fenólico total del fruto de melón. La calidad nutraceutica (capacidad antioxidante y contenido fenólico) de los frutos fertilizados con las soluciones orgánicas fue mayor que en los melones fertilizados con la solución Steiner. El tratamiento con lixiviado de vermicompost obtuvo los mayores valores de capacidad antioxidante y contenido fenólico de todos los tratamientos, resultando un 46,1\% mayor en capacidad antioxidante (método $\mathrm{DPPH}^{+}$), y 29,3\% mayor en contenido fenólico que los frutos fertilizados inorgánicamente. Las soluciones obtenidas a partir de vermicompost (lixiviado y té) son alternativas viables de fuentes nutricionales para la producción de melón Cantaloupe hidropónico bajo condiciones de invernadero, el cual tendrá una calidad nutraceutica mejorada.

Palabras clave: Capacidad antioxidante, Cucumis melo, fertilización orgánica, nutraceutico. 


\section{References}

Benavides-Mendoza, A. 2002. Ecofisiología y Bioquímica del estrés en plantas. Universidad Autónoma Agraria Antonio Narro, Departamento de Horticultura, Buenavista, Saltillo, Coah. México. 228 pp.

Bourn, D., and J. Prescott. 2002. A comparison of the nutritional value, sensory qualities, and food safety of organically and conventionally produced foods. Crit. Rev. Food Sci. Nutr. 42:1-34.

Brand-Williams, W., M.E. Cuvelier, and C. Berset. 1995. Use of a free radical method to evaluate antioxidant activity. LWT-Food Sci. Technol. 28:25-30.

DeFelice, L.S. 1995. The nutraceutical revolution, its impact on food industry. Trends Food Sci. and Tech. 6:59-61.

Dixon, R.A., and N.L. Paiva. 1995. Stress-induced phenylpropanoid metabolism. Plant Cell 7: 1085-1097.

Esparza-Rivera, J.R., M.B. Stone, C. Stushnoff, E. Pilon-Smits, and P.A. Kendall. 2006. Effects of ascorbic acid applied by two hydrocooling methods on physical and chemical properties of green leaf lettuce stored at $5{ }^{\circ} \mathrm{C}$. J. Food Sci. 71:270276.

Ferrante, A., Spinardi, A., Maggiore, T., Testoni, A., and P.M. Gallina. 2008. Effect of nitrogen fertilization levels on melon fruit quality at the harvest time and during storage. J. Sci. Food Agr. 88:707-713.

Guerrero, J.C., L.P. Ciampi, A.C. Castilla, F.S. Medel, H.S. Schalchli, E.U. Hormazabal, E.T. Bensch, and M.L. Alberdi. 2010. Antioxidant capacity, anthocyanins, and total phenols of wild and cultivated berries in Chile. Chil. J. Agr. Res. 70:537-544.

Häkkinen, S.H., and A.R. Törroönen. 2000. Content of flavonols and selected phenolic acids in strawberries and Vaccinium species: influence of cultivar, cultivation site and technique. Food Res. Int. 33:517-524.

Hallmann, E., and E. Rembiałkowska. 2012. Characterisation of antioxidant compounds in sweet bell pepper (Capsicum annuum L.) under organic and conventional growing systems. J. Sci. Food Agr. 92:2409-2415.

Herms, D.A., and W.J. Mattson. 1992. The dilemma of plants: to grow or defend. The Quarterly Review of Biology 67:283-335

Lombardi-Boccia, G., M. Lucarini, S. Lanzi, A. Aguzzi, and M. Cappelloni. 2004. Nutrients and antioxidant molecules in yellow plums (Prunus domestica L.) from conventional and organic productions: a comparative study. J. Agric. Food Chem. 52:90-94.

Ochmian, I. 2012. The impact of foliar application of calcium fertilizers on the quality of high bush blueberry fruits belonging to the 'Duke' cultivar. Not. Bot. Horti. Agrobo 40:163-169.

Olivos, A., Johnson, S., Xiaoqiong, Q., and C.H. Crisosto. 2012. Fruit phosphorous and nitrogen deficiencies affect 'Grand Pearl' nectarine flesh browning. Hortscience 47:391-394.

Preciado-Rangel, P., M. Fortis-Hernández, J.L. García-Hernández, E. Rueda-Puente, J.R. EsparzaRivera, A. Lara-Herrera, S.M.A. Segura-Castruita, and J. Orozco Vidal. 2011. Evaluación de soluciones nutritivas orgánicas en la producción de tomate en invernadero. Interciencia 36:689. 693.

Salandanan, K., M. Bunning, F. Stonaker, O. Külen, P. Kendall, and C. Stushnoff. 2009. Comparative analysis of antioxidant properties and fruit quality attributes of organically and conventionally grown melons (Cucumis melo L.) Hortscience 44:1825-1832.

Steiner, A.A. 1984. The universal nutrient solution. Proceedings 6th International Congress on Soilless Culture. ISOSC. Lunteren, Netherlands. p. 633-649.

Toor,_R.K., Savage, G.P., and A. Hee. 2006. Influence of different types of fertilizers on the major antioxidant components of tomatoes. J. Food Compos. Anal. 19:20-27.

Tuteja, N., and S. Mahajan. 2007. Calcium signaling network in plants. Plant Signaling \& Behavior 2:79-85

Weibel, F.P., Bickel, R., Leuthold, S., and T. Alfoldi. 2000. Are organically grown apples tastier and healthier? A comparative field study using con- 
ventional and alternative methods to measure fruit quality. Acta Hort 517, 417-426.

Zhao, X., Carcy, E.E., Wang, W., and C.B. Rajashekar. 2006. Does organic production enhance phy- tochemical content of fruit and vegetables? Current knowledge and prospects for research. Hort. Tech. 16:449-456. 
